\title{
Theoretical studies focused on gender discrimination against Roma women in the Czech Republic
}

\author{
Marek Merhaut ${ }^{1}$ \\ Institute of Hospitality Management, Prague, Czech Republic
}

Discrimination affects the lives of many Roma women in different areas of their lives. Issues such as unequal access to the labour market for women and men, domestic violence, stereotypical expectations of the roles of women in society, other expectations in education for women and men are deepening in the context of discrimination and ethnicity expectations. Roma women in the Czech Republic are among the groups most at risk of unemployment. However, repeated failures to find a job reduce their self-esteem and, unfortunately, predetermine their future use in the family circle and in the natural community where they are more or less the role of careers. Relationships in the Roma community are much stronger than usual in Czech society. Many Roma women have a subordinate position towards husband and other male family members. Roma families often do not allow a woman to study, according to her usual practice; she should take care of her family and children. The current need is to listen to the voice of Romani women who strive for full participation in the Czech society and to act in this sense also on the attitudes of their surroundings.

Keywords: equality, gender, roma minority, religion and gender, race, discrimination, Romani women.

\section{Introduction}

The present article deals with the life of Roma citizens living in the Czech Republic and is primarily focused on discrimination against Roma women. The aim of the present paper is to analyze the problems of gender discrimination against Romani women in the Czech Republic. The presented theoretical study highlights the ethnic problems such as unequal access of women and men in the labour market, domestic violence, and stereotypical expectations of women's roles in society. Last but not least, the article highlights the issue of Roma ethnic education, which is deepening in the context of discrimination, ethnic and cultural differences. Stewart (2017) argues, that in recent years a number of calls have been made for a 'new paradigm' in Romani Studies. Sometimes referred to as 'critical Romani Studies', the proposed research agenda focuses on racism and its importance for Roma and Romani identity, as well as issues arising from inequalities and the structural discrimination of Roma. Drawing from post-colonial studies, feminist critique, intersectionality and 'critical race theory' the advocates of this approach have suggested that who speaks may be as or more important than what they have to say. In this contribution to the debate I question whether discussing issues around the 'authority to speak' will advance the substantive issues that ought to concern all scholars in this field, Romani and non-Romani. We confront disastrous social conditions in some regions, and - due to the continuing failure, in countries like Czech Republic, Hungary and Slovakia, to improve the employment rates of the uneducated and unskilled (Köllö, 2014) - this has produced the paradoxical outcome that uneducated and unskilled Roma migrants can get jobs in high-wage Britain and not in low-wage Czech Republic, Hungary or Slovakia. Stewart (2017) further argues that the fact that, twenty-five years into a market economy, little is improving for the Roma is a source of agony for all observers and enraging to those on the ground, the teachers, social workers and local authorities who deal with the consequences year in year out. Roma is the word that many Roma we Theoretical studies focused on gender discrimination against Roma women in the Czech Republic. Gagnon and Sauca (2014) informs that the Roma is the word that many Roma uses to describe them; it means "people," according to the Roma Support Group, (RSG) an organisation created by Roma people to promote awareness of Romani traditions and culture. They are also known as Rom or Romany. According to Open Society Foundations, some other groups that are considered Roma are the Romanichals of England, the Beyash of Croatia, the Kale of Wales and Finland, the Romanlar from Turkey and the Domari from Palestine and Egypt, as shown in Figure 1.

Helakorpi, Lappalainen and Mietola (2018) inform that the Travellers of Ireland are not ethnically Roma, but they are often considered part of the group. The Roma are also sometimes called Gypsies. However, some people feel that a derogatory term, a holdover from when it people have thought these people came from Egypt. It is now believed that the Roma people migrated to Europe from India

${ }^{1}$ Correspondence; Department of Marketing, Institute of Hospitality Management, Prague 8, Svídnická 506, 18100 Praha 8. E-mail: merhaut@vsh.cz 
about 1,500 years ago. A study published in 2012 in the journal „PLoS ONE“concluded that Romani populations have a high frequency of a particular Y chromosome and mitochondrial DNA that are only found in people from South Asia. The Roma minority represents one of the essential minorities in the Czech Republic, which has always been a critical part of Czech society From the Czech majority, they differ in many aspects, such as traditions and customs, family groups, skin colour, etc., inform Love and Kundu (2016). Due to their diversity, the Roma often come into conflict with the majority society. The seriousness of the problems related to the Roma community is mainly because a significant part of the Roma minority in the Czech Republic belongs to the group at the lowest social level with high unemployment, low level of education and a disproportionately large share of criminal activity due to the total population. Intercultural education should contribute to the improvement of state of the art and to new educational approaches - in the ethnic minority, to develop its cultural specifics and at the same time to know the culture of society as a whole, the majority to understand the necessary details of other nationalities living in an ordinary state, inform Hrabaňová and Albert (2018). The Roma do not follow a single faith; instead, they often adopt the predominant religion of the country where they are living, according to Open Society, and describe themselves as "many stars scattered in the sight of God." Some Roma groups are Catholic, Muslim, Pentecostal, Protestant, Anglican or Baptist. The Roma lives by a complex set of rules that govern things such as cleanliness, purity, respect, honour and justice. These rules are referred to as what is "Romano." Romano means to behave with dignity and respect as a Roma person, according to Open Society. "Romanité" is what the Roma refer to as their worldview. IOM (2003) inform that there are many Romani families who have prospered since 1989, families who found new economic and political freedoms offering opportunity for enrichment and empowerment. The grand palaces of more than a handful of Romani communities in Czech Republic attest to such success. But many more have lost much of the security and all the meagre prosperity they enjoyed under communism.

In order to obtain a relevant analysis of the given situation, we have to ask several research questions, which we will try to answer on the basis of the obtained facts.

1. For example, how do Romani traditions affect the position of women and men in the Roma community and what impact does it have on education, employment, the economic situation of Romani women?

2. How are employers, schools, or other institutions, treated by Roma women and what role do stereotypes play in them?

3. What extent the problem, of discrimination of Romani women, treated in Government Strategy Papers on Gender Equality and the Integration of the Roma Community in the Czech Republic?

4. How does the European Union build the issue of discrimination against Roma women?

\section{Discrimination based on racial prejudice begins at Roma children's}

One of the main problems associated with the Roma ethnicity is the low level of education compared to the majority of society. While Roma attends school, they only have primary or lower education. Poor education has a negative impact on the status of the Roma in the labour market because it generates unskilled work in general but has difficulty in promoting the current labour market because the demand for unskilled labour is continuously decreasing. Cashman (2016) informed that the reasons for under-education of a Roma ethnic group can be considered insufficient motivation to gain the education or anticipate discrimination in the labour market. Another reason is the fact that knowledge and the environment in which Roma children grow up is very different from most. In recent years, Romani children were automatically placed in individual schools, thereby preventing access to further education. It was their separation within the education system, said Messing (2017). Multicultural education of pupils in schools is based on equality of access to individuals and minorities of the majority society (Constantine, 2017; Johnson \& Hinton, 2019; Lafer \& Tarman, 2019; Ngyen, 2018). The objective of the relationship between the national minority and the majority is the ethnic, linguistic and cultural diversity of national minorities from the rest of society - majority. The Ministry of the Interior of the Czech Republic (2008) in the report "Education and needs of Roma children and youth" states that a large proportion of Roma children are not sufficiently prepared to start schooling and their disability does not compensate for the provision of pre-school education. MŠMT (2010) informed that the most significant disadvantages are the lack of knowledge of the Czech language and the family environment that Roma children cannot usually prepare for school attendance, the report said. Roma children have low career aspirations; they do not believe they will gain a prestigious vocation also because they are mainly missing positive patterns. "On the other hand, the school environment does not usually allow Roma children to accept and motivate them to overcome their disadvantages", informed Ministry of the Interior of the Czech Republic.

New and Kyuchukov (2018) point out that the ethnic disparity, different education, and an overall relationship to education cause the failure of the Roma child. Tensions are transmitted to school: "Few Roma children in school will stand. At home it is good, it is bad at school. She feels like a 
boyfriend. He is constantly on guard. "He is always waiting for revenge to come again: "Preventing Beats around", recalls Hrabaňová and Albert (2018). Teachers, experts have looked for preventive measures and ways to prevent a negative relationship with the school. For children from a socially hostile environment and for the Roma population, they found one of the methods of setting up preparatory classes. "Educational work of a teacher in an introductory class requires teachers with a wide range of positive qualities. Above all, he must be an experienced pedagogue, an educated psychologist, a versatile specialist who is continuously educated", says Rostas and Kostka (2014). However, most importantly, a teacher must be patient and self-sacrificing, relaxed and inventive, working with children from diverse family background, with the broadest range of abilities and possibilities (Martincová, \& Andrysová, 2017).

As Cashman (2016) further states, to be a teacher of a Roma child requires being a creative person, acquainted with the history and culture of his wardens. According to information obtained by the International Federation of Human Rights from the Czech League of Human Rights, many primary schools in the Czech Republic are reluctant to accept Romani pupils. This approach can be explained, by the reactions of non-Roma parents, who in many cases have deported their children from integrated schools, fearing that the level of school drops with the advent of Roma children, or just because of prejudice against the Roma. Alexiadou and Norberg (2017) argue that, at the discursive level, the Strategy has engaged positively with the politics of Roma inclusion and has introduced a number of new issues in the public debate. In such a situation, Cashman (2016) on the other hand, points out that Roma children are subjected to an examination to examine their ability to be enrolled in regular educational establishments. If the parents decide to send their children at a specific school, this decision is in fact in line with the intention of running regular school institutions not to accept a more significant number of Romani children as their arrival could lead parents of non-Romani children to drop out of the school. Authors New and Kyuchukov (2018), argues that Romani education policy recommendations often feature a defence of the linguistic human rights of Romani children, rights that have never been respected by the majority populations and institutions of European nations. Cashman (2016) states, that in many ways, all discussion about the problems of education of Romani children revolves around differences in culture and language between minority and majority populations, even when questions about "rights" to access, or protections against discrimination, are fore grounded. Messing (2017) in her study: Differentiation in the Making: Consequences of School Segregation of Roma in the Czech Republic, Hungary, and Slovakia, argues that ethnic segregation is not limited to the placement of Roma students in separate schools; interschool segregation is similarly widespread in the countries of Central and Eastern Europe, though this practice is rarely discussed (James, 2019; Messing, 2014; Rostas \& Kostka, 2014; Szalai \& Schiff, 2014, Šimon, Ales, \& Švec, 2017). It is not at the forefront of sociological and policy discourses for various reasons: it is difficult to identify such practices, as data on the ethnic identity of students broken into parallel classes is evidently not accessible and also because many policy makers believe that segregation ends once children study under the same roof. Cashman (2016) then points out that Intra-school segregation served the interest of local majorities, maintaining physical and social boundaries that were consistent with the social hierarchies constructed along the lines of ethnicity and race. Techniques of segregating Roma children within the school may vary forming specializations, providing ethnic minority education, creating zero classes for disadvantaged students - but the rationale behind such organization of the school was either the racist views of headmasters themselves or the need to comply with parents' antiRoma prejudices coming from the ethnic majority, to prevent "white flight." These differences in the motives behind segregation evidently had an effect on the everyday experience of Roma students at school. Intra-school segregation made ethnic hierarchies an explicit and daily experience for both Roma and non-Roma students, says Messing (2014).

\section{Migration of Roma Ethnicity}

Romani migrants become global players in international politics by virtue of their agency - they point to discrepancies among the rules set to govern in this space. By analysing additional cases, we will be able to witness further ways that Romani individuals react to irregularization through unconventional practices. It is this creative agency that precisely demonstrates that there are possibilities to move beyond the limitations set by those who position Romani migrants on the margins of European citizenship inform Sardelič (2017). In the Czech Republic, Roma has the status of a national minority, which grants them exclusive rights to their national minorities. Regarding the current number of Roma in the Czech Republic, official statistics based on censuses differ with estimates. According to views on the website of the Government Council for National Minorities (2017), there are currently 150,000 to 300,000 people belonging to the Roma minority in the Czech Republic. Similarly, the purpose of Council Directive 2000/43 / EC of 29 June 2000 implementing the principle of equal treatment between persons irrespective of racial or ethnic origin and Council Directive 2000/78 / EC of 27 November 2000 lay down a general framework for equal treatment in employment and occupation, prohibit all direct or indirect discrimination on grounds of race, ethnic origin, religion or belief, disability, age or sexual orientation in the areas to which they apply. Bhabha, Matache, and Marti (2017) inform, that the introductory provisions of these 
directives state that "an assessment of the facts which lead to the finding that there has been direct or indirect discrimination lies with the national judicial or other competent authorities following national law or practice. Roma is considered to be an ethnicity that is constantly changing their place of residence. Here we can see other causes of Roma unemployment, namely low mobility and housing problems. In the past, the pressure of the majority of society has led to the establishment of nomadic ethnic groups. Sardelič (2017) points out that, by investigating and comparing the position of Romani migrants with and without EU citizenship in two contexts, I claim that different states render Roma as 'unwanted migrants' by "irregularizing" their migrant status. The case studies in this article demonstrate that the position of many Romani migrants is specific when compared to the position of other irregular migrants. The "irregularization" of their migrant status and the restriction of accompanied rights occur even in cases when this status should be considered regular due to their de jure citizenship. Isin (2015) says that the process that contributes to the "irregularization" of migration, to use the concept of positions Romani migrants in a legal limbo somewhere on a scale between regular and irregular migrant status, where they also fall into the regime of deportability. This legal limbo points to the fact that there is a 'dialectical process' (De Genova, 2015: 6) between inclusion and exclusion rather than a binary opposition. That is why the idea of the constant movement of Roma is currently mistaken. Roma is accustomed to living in large numbers of families who, in case of emergency, are helping each other. "In the case of relocation, there is often no shift for better work, but for family members, or for available housing, which is usually in unspeakable areas due to discrimination in the housing market", Brandth, Halrynjo and Kvande (2017) states. The factors driving migration are social, political and economic: worsening inter-ethnic relations, the rise and spread of violence and political racism and fear of racist attacks, deprivation and deterioration of living conditions for the poorest, and stigmatisation of ethnicity. As a result of the "Velvet Revolution" until 1989, the Roma formed an unskilled labour force that was mainly used in industrial areas such as Northern Bohemia and Moravia. At present, however, these zones are experiencing bankruptcy and are being hit by unemployment. Due to low mobility, Romani ethnicity remains in unspeakable areas and spreads many unemployed. Sardelič (2017) argue that the last strand of the theory upon which I base my analysis is the enactment of European citizenship (Isin, 2015). "Romani migrants, both within the EU and on its margins, enact European citizenship from their position as semi-citizens and migrants", informed ION (2003).

Based on Beaman's (2016) statement, the housing situation is particularly unpleasant for the Roma as there is considerable discrimination in the housing market due in particular to fears of not paying rent, damage to property, etc. Given the above, housing is offered to hostels and similar facilities in unsurpassed peripheral areas where families are placed socially weak. There are often contracts to be concluded for inadequate housing, which is unregulated, with high rent and hence disadvantageous. In this way, there is a concentration of individuals and families with varying degrees of inappropriateness, as households living in a healthy environment may also rely on housing in similar areas, says Matras (2015). Within the framework of achieving maximum cost-effectiveness, the municipality's housing policy has the effect of concentrating socially disadvantaged people into one locality with less expensive housing, creating a ghetto, as shown in Figure 2, 3 and 4.

Individuals and families here settled gradually adapt to the new conditions and progressively lose their desire to anchor outside. Apart from creating ghettos, however, systematic deprivation of problem populations may occur. Matras (2015) further informs that the village is taking steps to force individuals, for example, to shut down hostels to move out of the community. Families are then forced to concentrate in places where housing is available, but living conditions inadequate. IOM (2003) latest present information that if any migration of Roma from poor settlements in eastern Slovakia to the more prosperous Czech Republic took place before year 2000, the media and the general public did not pay much attention, as shown in Figure 5.

The alarm started in year 2000 when almost 800 Slovak citizens (an overwhelming majority of Roma) applied for asylum. In 2002, the total number of applications from Slovakia rose to 843 (third position in Ukraine and Vietnam) and rose 1055 in the following year informed IOM (2003). The media was overwhelmed by the description of the "floods" of the Slovak Roma, and the Immigration Police considered possibilities for the Roma to recognise and not let them into the republic among other Slovaks. The whole matter was complicated by the fact that Czechoslovakia and Slovakia were in the customs union at that time, and that the citizens were free to move. What exactly happened and why did the migratory wave suddenly rise? The answer is simple - Slovak Roma has discovered a wonderful opportunity to abuse the "Czech state of welfare" (IOM, 2003).

\section{Roma women fall into groups that face discrimination in the Czech Republic}


Blasco (2015) presents Roma women as women who expected to avoid stepping over any dishes that could be associated with food, especially while sitting at lower or coffee tables. What is more, women must not step over any drinking water sources, such as water tanks either. Based on Romani culture, women are also forbidden to participate in the preparation of any dishes during their periods. Concerning food, there is an exciting tradition in the Roma community which is still valid somewhere and which is connected with the person who prepares dishes, present Chancer and Watkins (2006). A great many of Romani people would not eat food that is made by "gadjo"2 (non-Romani) or by an ethnic Romani who lives in another ethnic subgroup where the concepts of shame and honour may differ in details. On the other hand, some Romani people make no difference between "gadjo" and Romani people and are not afraid of pollution of their souls or bodies, as shown in Figure 5.

Sending women to the workplace and the man for the income and the pub would have been unacceptable in our own culture and our households, and therefore we should not protect them as part of their culture with the Roma. Bego (2015) points out that thus, the inferior position of a woman in the Roma community must be critically examined concerning gender roles and power mechanisms. Related ethnographic descriptions can be used to understand better how the Roma community works, but they must not be uncritically embedded in the summary of the culture that is needed in the name of Romani pride and the suppression of ethnocentrism, says Blasco (1999). The marginalisation of Romani women in human rights activities highlights the Roma activist Alexandra Oprea in 2014 notes that the gender dimension, is not taken into account in the fight for Roma rights and that the ethnic aspect of the struggle for women's rights is respected. These activities often neglected the experience of Roma women. According to the EU Fundamental Rights Agency 2014, the Czech Republic has the highest proportion of Roma women active in the labour market among the EU Member States. 36\% of Romani women are involved in the labour market, with an average of $21 \%$ in the EU. However, we also have the highest percentage of Roma women who feel discriminated by ethnicity in their search for a job, a total of $35 \%$, compared to an average of $22 \%$ in the EU. Cahn (2015) points out that Roma women fall into groups that face discrimination in the Czech Republic. They are discriminated against because they are women, by ethnicity or age. Other factors that play a role in the access of Roma women to the labour market are higher demands on family and household care, education and low or no qualifications, this confirm Ruggiu (2016). Problems in access to the labour market are, however, also faced by Romani women who have achieved higher education. Typically, Roma girls have married already between the ages of 18 and 21. The tradition of early marriage and pregnancy is then deprived of the possibility of deciding on their further direction as shown in Figure 7.

The pressure on the part of the Roma community does not allow them to choose a different way of life and influence the beginning of sexual experience, marriage, pregnancy and childbirth, says Nelson (2015). Another thing is that domestic violence against Roma women tends to be in their immediate social environment - and this affects their physical and mental health. The question of physical and psychological oppression, threatening her health and safety, is thus a daily reality in a woman's life (Weinerová, 2014). The situation of Roma women, in general, has a significant impact on the existing social problems in the region, including health care, employment, education, human rights, social integration and many others, says Cahn (2015). Problem-solving at the fundamental level is hampered by the fact that Roma people do not trust the state administration and public administration authorities and try to avoid contact with them. Roma usually lives on small-scale sales, begging, theft, or prostitution, as shown in Figure 8.

Romani women, therefore, have little opportunity to defend their rights, to lobby for their legitimate interests, and to mobilise members of their community. Bego (2015) argues that a severe problem is the policy of state structures concerning the Roma, which entirely or partially ignore Roma women's issues. However, how can we effectively set up cooperation with Romani women who have been victims of domestic violence? It depends on the causes of domestic violence in Roma families and whether there are specific differences between the victims of domestic violence among women from the majority and Roma women. Some specificities of Roma culture, associated with, for example, Roma women's access to education, the labour market or health care, are considered to be the cause of isolation and limitation of the freedom of Roma women. However, it is important to remember which Roma groups we are talking about and in what geographical, social and political contexts these Roma groups are moving, says Helakorpi et al. (2018). The traditional understanding of the relationship between man and woman in Roma families is diverse, as are the different Roma communities across Europe. At the same time, these relationships are subject to dynamics, which is connected with the environment in which Roma families and the broader Roma communities live. Blasco (1999) states that gambling or alcohol and drug addiction, which in many cases today cause the breakup of the Roma family and domestic violence is not surprising in the context of socially excluded localities. In the eyes of the majority and fact the inhabitants

\footnotetext{
${ }^{2}$ Gadje, Gadjo is the generic term used by Romani people to refer to non-Roma citizens.
} 
of these localities, the socially pathological phenomena in this environment become admissible, says Nelson (2015). The problem is much more marginalised - and with him and his victims.

Bego (2015) argues: "Nevertheless, some Romani women perceive domestic violence as a problem in this environment and consider ways to solve such a problematic situation". However, some contexts are involved in these processes, which mix the specificities of socially excluded localities and certain aspects of Roma culture. In practical terms, when a woman with children decides to leave an aggressor, the question arises as to where to go. Nelson (2015) states, on the other hand, that other members of the family often live in a limited space in which there is no room for other people. Despite the unhealthy relationship with the aggressor in such a family, however, a Roma woman has many other social ties that do not allow her to solve the situation at home, but at least give her emotional and psychological support, a sense of belonging.

If she decides to leave with children outside the Roma community, she risks not surviving. They will lose access to already limited economic resources that the Roma can provide each other, says Kóczé, Zentai, Jovanovič, \& Vincze (2019). Beyond the city, it will also be at the lowest social level. The stigma of the domestic violence victim will be extended to include the status of a Roma victim of domestic violence who has neither education nor work, but more children than is desirable from the surrounding society. In the Roma community, therefore, the Romani woman has an increased chance of survival. It is orientated in it, draws on it, and at least minimises it for survival (Chancer \& Watkins, 2006). The system for assisting victims of domestic violence in Roma families should therefore not omit these aspects. Roma culture, which is considered by many to be the cause of isolation and violence against Romani women is at the same time a source of salvation for these women, says Matras (2015). An effective system of assistance to these Roma women should count on it.

A Romani woman can only be a woman, exposed to very unpleasant situations. However, like "Romka" she even "provoked" her invaders even more, say Matras (2004). It is almost predestined for white men to behave like inferior and therefore lighter prey to her. Such women (and even parts of men) are, as the campaign has shown, really a lot and the stories are even more. I could also contribute to my fire in the field, and I know I am no exception. On the contrary, I vainly wonder who among my friends with sexual harassment, especially in public, did not meet. Chancer and Watkins (2006), argue: "However, according to discussions, social networks see that opening this topic is more than needed. That there are still plenty of people who do not believe or lessen the severity of the situations described". Moreover, there will also be those who make the guilty victim of a severe crime, informed Linehan (2015). The police academy, for example, has published a textbook in which future police officers explain that a woman can sometimes provoke a violent offender by her behaviour, for instance, by her flirt or laziness. Is not it surprising that the man wrote it?

The Romani woman does not become a "mere" object conditioned by sexual lust, but also the object of humiliation and degradation of its dignity for its ethnic origin. This woman, who already has a low standing position in some Romani families, is also exposed to a secondary role among the victims of sexual harassment, informed Cahn (2015). To compensate for the disadvantage of Romani girls and women who are often faced with double discrimination - as members of the minority and as women within their own community, the Department of Human Rights. The Health and Human Rights Journal is calling for papers for a special section on Romani Global Diaspora: Implementation of the Right to Health to be published in December 2017 (Bhabha, Matache, \& Marti, 2017) The special section aims to examine the implementation of the right to health in the case of Romani populations across the globe. In this article was mentioned that for 50 years Romani women have been subjected to sterilisation without their consent, and often without being informed that such an operation would be performed on them. Cahn (2015) in his article highlighted the issue of sterilization of Roma women in the Czech Republic. The papers by Claude Cahn (2015), demonstrate that discrimination has been a triggering cause of ill health for Roma. By engaging in the forced sterilization of Romani women since the 1970s, Czechoslovakia (and the Czech and Slovak states later on) did not do anything exceptional; rather, they joined the ranks of modern states that have executed and still are executing bio power policies upon groups ideologically deemed "degenerate," be they the chronically ill, people living with disabilities, ethnic minorities, the politically unreliable, or the poor. Forced sterilizations are a striking example of an intervention by the modern state to control populations and to limit the reproductive strategies of any group ideologically deemed to pose a "degenerative" threat to society as a whole. Most Gypsy women were given orders or permissions for sterilization due to social reasons or mental deficiency. Both reasons had to do with their ethnic origin and lifestyle. The social grounds for sterilization and Gypsy ethnicity were interconnected in that, in an increasingly their traditional lifestyle - which consisted of travelling from farm to farm doing rurally related work tasks, caring for and selling horses, practicing traditional female handicrafts, etc. - and Gypsy ethnicity more generally came to be seen as exemplifying an anti-social and undesirable lifestyle, 
with the Gypsies emerging (or being defined) as a social problem that required a solution stats Cahn (2015).

\section{Risk factor - trafficking in Romani women in the Czech Republic}

After 1989, trafficking in human beings, the victims of which were women from Central and Eastern Europe, grew significantly. It is currently known that the Czech Republic has become not only a country of origin but also a destination and transit country. Official statistics that would accurately capture the situation of women trafficking in the Czech Republic can hardly be created. One reason is that trafficking in human beings is illegal. According to both police and field staff, it can be concluded that only a small proportion of trafficked women are in contact with the police or support organisation. (It must be emphasised that trade in women cannot be identified only with prostitution, illegal migration to the sex industry or smuggling in general).

Romani women carry other business-related risk factors in life, based on the reality of the sociocultural environment in which they grow up and live. Attitude to Women's Rights - The Messing (2017) argue, that the Roma community is traditionally patriarchal; women, besides "phuri day" they did not enjoy great respect in the community. This attitude to women persists to the present (and is worsening with the collapse of the social situation of communities), its bearer is not only the male parts of the community, but most of women also accept this fact, and it seems to them self-evident. Issa and Mueller (2017) say that the dominant position of a man who needs his power to manifest may result in domestic violence directed at his wife, where children are often present. The study: Apart or together: motivations behind ethnic segregation in education across Europe, even claims that domestic violence in Roma families can be either the result of cultural habits or the consequence of a bad social or economic situation Messing (2014). This assertion also supports the theory of poverty culture, which is currently applied to the situation in Roma communities. Orientation to the presence - A risk factor for trafficking in women may be the perception of time, (e.g.) they are likely to accept an offer to get a good job abroad without trying to determine the degree of risk. Roma emigration likelihood, that a girl or woman travels abroad increases the fact of contemporary Roma emigration, says Weinerová (2014). Whether the reasons for Roma emigration are economic or whether the reason for leaving the country is fear of racial discrimination, Romani women and girls may find themselves in a foreign environment beyond the borders of the state. Exoticness - Schlager (2017) in her study: The situation of Roma women in Europe, points to the fact that Roma women are becoming more and more "exotic business material.

To these risk factors, which are significant from the Romany community, it is necessary to mention other factors related to the situation in the Czech Republic. Geographical Location - An advantageous geographic location is a reason why the Czech Republic is a country of origin, a transit country and a target country for trade with women. The economic situation of state - The financial condition of the state is another factor that affects commerce. Differences in wages of men and women Differences in wage levels persist mainly in less qualified professions (women's salaries account for $75 \%$ of the salary that men receive for comparable work) and is one of the causes of rising unemployment among women. High profits from women's trade and small risks - Trade in women is a kind of organised crime that brings top benefits. Estimates are up to four times higher than the profits from drug trafficking.

There have been several factors influencing the acquisition of OSL information in localities, in particular from workers and workers who move directly in Roma communities and community women. Trade in women is often confused with prostitution; many taboos are being tied to Roma prostitution. Prostitution as such is unacceptable according to the traditional values of Roma communities, its operation being an unthinkable "shame" for the family of women and the woman itself, says Beaman (2016). The taboo associated with prostitution was more or less reflected in the many interviews that have been conducted; the same taboo was also reflected by many questioned as an obstacle to working with OSL and prostitution. Edwards (2017) argue that very terms "trafficking in human beings" or "trafficking in women" are not well known. The OSL is often confused with prostitution, in some cases, the idea of a trading process is framed by "stories" about girls kidnapped during a footprint or a dark park, as a synonym for trafficking in women, the phrase "white meat trade" appears. For more information, the phrase "woman was sold" or "forced to prostitution" appeared more understandable, inform Edwards (2017). Past and present locations visited were cases of trafficked women and girls or cases most likely to be trafficked. Compared to other issues (such as housing), OSL is perceived as a marginal problem, as it is "only" about individual cases. In the interviews, however, it has often been assumed that the existence of OSL can be more or less latent, especially in the Ostrava region and the Ústí nad Labem Region, but it is not possible to obtain accurate information. The situation in the individual visited regions is different for OSL; while girls from the Ostrava region are or maybe trafficked (sold or forced to prostitution) to other parts of the Czech Republic or abroad, in the Ústí Region, it is more about forced prostitution within the region or trading overseas. The girls from the other areas are also brought to the Usti region. Slovakia. In Prague, the situation is somewhat different; Prague girls and women - primarily, because of the factual possibilities of obtaining finance - are the least vulnerable to trading in Ostrava or Ústí, as shown in Figure 
9. More serious is the commercial sexual abuse of Roma children (boys), especially in the form of boy prostitution. Roma women and girls are trafficked primarily for prostitution as trafficked Roma women (or women who are likely to be abused in the prostitution environment), as shown in Figure 10.

\section{Method - Research focused on the Roma minority in the Czech Republic}

Mutual trust between people in the Czech Republic is diminishing, tolerance for minorities also disappears. The often heard statement that Roma has a lot of children has not been confirmed in the exclusive research. Nearly a third of Roma (29\%) have two children, more than a fifth (21\%) of the three children, and only a fraction of the respondents (19\%) have only one child. More detailed information on the status of Romani women in the Czech Republic is provided by a new publication of "Slovo 21"- Civic Association. The results of exclusive research can serve as a relevant source, for example, for the development of a Roma integration strategy or for programs that want to respond to the real needs of Roma women in the Czech Republic. This latest, bat not last survey (managed by Czech Government), was conducted from September 2013 to May 2014, and the questionnaires were completed by 600 Roma from 17 to 77 years old from 23 cities in the Czech Republic. A questionnaire survey was conducted by 20 trained Roma women and included topics proposed by members of the Roma women's group "Manushe". This section of the "Slovo 21" organisation has been active in the field of empowering Roma women in the Roma community and society in general for years. Subsequent research in 2017 aimed at the tolerance of Czech citizens towards minorities revealed the fact that there is a lack of trust among people in the Czech Republic, and the degree of tolerance for certain minorities, especially Muslims and immigrants, in general. In the long run, they also refuse to have Romans next to each other. This results from the latest collection of data in a long-term survey of the Faculty of Social Studies of Masaryk University in Brno. They used the same research as presented by Strubing (2018). The results presented the journalists on Wednesday 27th of September, 2017. Apart from the Roma, people near them do not want alcoholics and drug addicts for a long time. In recent years, tolerance towards ethnic and religious minorities has declined significantly. While in 1991 the Muslim did not want about $20 \%$ of the neighbour, in 2017 it was $58 \%$. Similar developments have been noted by experts in immigrants and foreign labourers. Neighbouring them in 2017 would still not want every fifth Czech.

"In a few generations, the Czech society was quickly deprived of its experience of otherness, especially ethnic and religious, but in the 1990s, these negative attitudes managed to decrease slightly, and the trend started in a positive direction, and only in 2008 and especially in the last wave of research we see a change, "said Cashman (2015). It is the fault of the migratory crisis and Islamist terrorism. According to the study, the Czechs also less trust each other. Asked whether people can believe, only $23 \%$ of responded positively, which is the least during the whole research period. A significantly lower proportion is also in comparison with Western democracies, where the so-called interpersonal trust rate is around 40 $\%$. Long-term scientists are also exploring the trust of people in the institution. A significant decline in confidence is known in the latest survey by the media in general. Similarly, there are also international organisations such as the European Union and the United Nations, which people most trusted in 1999 and since then confidence has fallen. Especially between 2008 and 2014, it fell sharply, informed Isin (2015). Belief in the army, the police and the legal system grew.

"We have included institutions that emphasise the discussion and presentation of different opinions on the one hand and, on the other hand, those that symbolise order," said Gagnon and Sauca (2014). In interpreting the results, he suggests linking with the migration crisis, because while one type of institution is associated with its deepening, the other can be perceived as the one that protects it. Confidently, the researchers also dealt with conspiracy theories or a constitutional arrangement and, according to Cashman (2016), the results were surprising. With the statement that the official statement often covers the truth, up to $41 \%$ of the respondents agreed. More seniors and people with lower education tend to be more conspiratorial theories. The figures come from a series of repeated researches that took place in the Czech Republic within the framework of the European Comparative Project European Values Study. The analysis is repeated about nine years later, and the data thus formed creates a time series. Researchers can find out how specific value preferences and attitudes in the Czech Republic are developing. The research findings identified changes in the status of Roma when a woman became the primary source of income for the whole family, thus taking on the "traditional" role of a Roma man. For Romani men, this loss of traditional identity and relevant life roles can often lead to a life crisis that may be due to a low motivation to change its socioeconomic status for the better, and can also lead to sociopathological behaviour. Cases falling under this category are defined as "inoperative" men who have lost vital importance to the coexistence of the Roma family. Robnett and Anderson (2017) inform that both the roles associated with livelihood and the first cares of family care are now more secured by a Romani woman, pointing to her emancipation from being dependent on her partner. However, this emancipation is 
passive. Theoretically, a woman can become independent and independent, but at the practical level, she has a great deal of pressure from the near and distant social environment, says Cahn (2015).

\section{Roma integration strategy after 2020}

Fifteen European organizations urge EU countries to commit themselves to updating the Roma Integration Strategy after 2020, which has participated in a coalition of fifteen Roma and anti-racism organizations, calling on the EU Council and the governments of European countries to commit themselves to the update of the Roma Integration Strategy after 2020 The European Commission has submitted a proposal for this commitment to the European Parliament and the Council of the EU. "The Commission and Parliament are engaged in continuing to invest in Roma inclusion after 2020. It is now time for national governments to do the same, strengthen their fight against anti-Gypsyism and update and improves their strategies in line with the needs of the community by working with Roma civil society.. The Commission proposal presented highlighted critical elements for improving the Roma Integration Strategy, including the need to integrate Roma into mainstream policies, combat anti-Gypsyism, involve Roma in this process, address the diverse needs of diverse Roma communities, improve data collection, target refinement, and evaluate integration strategies.

"Until now, the fight against anti-Gypsyism has not been involved in Roma integration strategies in the Member States and has not substantially improved the situation of Roma throughout Europe," said Jovanovic (2016). Organisations are calling on European countries to recognise contemporary and historical forms of anti-Gypsyism as a specific form of racism and to take action against them. At the same time, they are calling on them to address the manifestations of anti-Gypsyism in public debates, public services and institutions and also to introduce the necessary legal and institutional mechanisms for prosecuting hate crimes and hate speech. Organisations emphasise the need for a common struggle against anti-Gypsyism, which they perceive as one of the leading causes of exclusion of Roma from society. The European institutions must ensure that the next EU budget cycle (multi-annual financial framework 20212027), currently under negotiation, takes into account the political priorities of the EU Strategy on Roma Inclusion. List of organizations involved: Alliance against Anti-gypsyism, Central Council of German Sinti \& Roma, European Network Against Racism, European Public Health Alliance, European Roma Rights Center, FAGiC Federación de Asociaciones Gitanas de Cataluña, Jaw Dikh Foundation, La Voix de Roms, Nakeramos, Nevo Parudimo, with Roma Active Albania, Romania, Roma Education Fund, RROMA Regional Roma Educational Youth Association (Macedonia), inform De Beco (2017).

\section{Discussion and Conclusion}

The position of members of the Roma ethnic group, the unfavourable situation in its education and its co-existence with the majority of society are problems that have been faced by the community and the state for a long time. The social exclusion of the Roma population is primarily linked to their elimination from the same labour market competition. The reasons for the marginalisation of Roma in the labour market are complex and long-term. Priority should be given to efforts to promote the integration of disadvantaged population groups through a wide range of social services, education, employment promotion programs and programs to improve the prevention of socio-pathological phenomena. The situation of Roma women in the labour market shows that income inequality is not just a difference in the remuneration of women and men for the same job. This problem is primarily related to the overall conditions under which specific women are allowed to enter the labour market. In the case of Romani women, it is about overcoming stereotypes about the Roma minority or roles that are expected from women in society or the Roma community. Like other women, Roma women in their careers are directed to areas of work that are perceived by society as specifically female and poorly paid. In areas such as social work or education, however, Romani women are often considered as experts only in the field of cooperation with the Roma community, which makes their application even narrower. To compensate for the disadvantage of Romani women in Czech society, the Czech Republic joined the international initiative named Roma Women Initiatives, which brings together about 135 organisations from Bosnia, Bulgaria, Croatia, the Czech Republic, Hungary, Kosovo, Macedonia, Moldova, Poland, Romania, Serbia and Slovakia. The Roma Women Initiative project was launched in 1999 as part of Open Society Institute programs. It aims to support the movement of Roma women in Central and Eastern Europe and to educate young Roma activists. Many Roma women in the Czech Republic strive to improve their conditions and chances of getting a quality education in the labour market. Highlighting the stories of successful Roma and Roma people is explained by the need for positive examples in the process of Romani emancipation. At the same time, they should point out that Roma as a group cannot automatically associate themselves with ignorance, crime or poverty. It is not an anonymous homogeneous mass, but individual people who have their unique life stories and meet in the shared experience of Romany. Striking successful stories bring with them other pitfalls. Success is redeemed by appealing to the social inequalities of the system, the scale of which is it assessed. When calling for successful stories, the requirement of consistent equality 
is hardly fulfilled, this illustrates just the case. If the Roma fall short of such a request, they can turn against themselves, typically against Romani women.

Besides, the emancipation policy thus set up the stories of successful Roma in contrast to the unprovoked environment in which their story was born. The stories of miraculous children from Roma settlements will thus always need a dirty, backward agreement with its inexperience, integrated Romani Roma excluded, educated uneducated. Finding the right forms of emancipation for Roma is extremely important, as it is crucial to promote Roma pride and create platforms on which Roma can share their experience. At the same time, however, other social inequalities must be taken into account, reflecting their power positions and avoiding even indirectly giving responsibility for their situation to the victims of oppression themselves. On the contrary, they brought with them various habits and predispositions alien and at times disagreeable to the Czech Republic, such as loudness, messiness and a refusal to emulate the Slovaks in their back-breaking toiling of the soil. Especially the tolerance for littered and unkempt yards has been a source of irritation, but nobody would use it nowadays as an excuse for barring Roma from living in the town. Roma undoubtedly sustains it to some extent, another element, too frequently unrecognized or unmentioned, that props it up is the gadjo tolerance of various patterns of conduct attributed to Roma. This tolerance played a role in the almost universally held conviction that the assimilation's project unfolded by the socialist regime was doomed to failure, which explains why most of the policies and doctrines handed down through the ranks of the nomenclature weren't implemented if they clashed with local 'essentialist' views of the limits of integration.

This article deals with the issue of the Roma population focusing on the monitoring of discriminatory expressions predominantly towards Romani women. The results of the general survey revealed the issue and subsequently pointed out the necessity of education and education of Roma ethnicity in the Czech Republic. Theoretical research revealed the issue of the individual or local outbreaks of racism and xenophobia towards Romani women; both from other national minorities and the minority of the population of the Czech Republic, but also that this issue of discrimination and abuse of Romani women also appears among the Roma population. Another problematic issue that emerged during the general examination of the subject matter is the issue of usury. Usury represents one of the most visible problems of the Roma community in the Czech Republic. The occurrence of usury in the Roma community and its projection into the motivational potential of Roma migration into EU countries lead to the need to create mechanisms that would eliminate the usury among Roma. In most cases, these are illegal gambling, illegal sale of apartments and, last but not least, one of the forms of usury, which is pimping with Romani women who often forced into street prostitution. There is no doubt that there are many barriers to detecting and proving this crime. It is the systematic removal of barriers to capture this possible but highly dangerous type of economic crime, and the police assistant could make a significant contribution, since usury is, among other things, the problem of missing police mechanisms to make it more useful to penalise. Unfortunately, the Czech police do not have "system sensors", which would allow the problem of usury, discrimination and xenophobia against Romani women to the extent that it actually exists today; the situation significantly complicated by the fact that the police usually do not trust the Roma community (this fact supported by the results of the above-mentioned theoretical survey).

\section{References}

Alexiadou, N., \& Norberg, A. (2017). Sweden's double decade for Roma inclusion: An examination of education policy in context. European Education, 49(1), 36-55, doi:10.1080/10564934.2017.1280342

Beaman, L., (2016). Social networks and the labor market. The Oxford Handbook of the Economics of Network. doi:10.1093/oxfordhb/9780199948277.013.30

Bego, I. (2015). Introduction: Gender equality policy in the European Union. In Gender Equality Policy in the European Union. Gender and Politics. Palgrave Macmillan, London, doi:10.1057/97811374371

Bhabha, J., Matache, M., \& Marti, T. S. (2017). The critical role of research in advancing Romani's Right to Health. Health and human rights, 19(2), 5-7. PMCID: PMC5739352, PMID: 29302158

Blasco, G. P. (1999). Gypsies in Madrid: Sex, gender and the performance of identity. Monograph Berg Publishers. doi:10.5040/9781474214858

Brandth, B., Halrynjo, S., \& Kvande, E., (2017). Work-family dynamics. London: Routledge. Doi:10.4324/9781315716794

Cahn, C. (2015). Coercive sterilisation of Romani women in the Czech and Slovak Republics. In Human Rights, State Sovereignty and Medical Ethics. Leiden, The Netherlands: Brill | Nijhoff. doi:10.1163/9789004280342_004 
Cashman, L. (2016). New label no progress: Institutional racism and the persistent segregation of Romani students in the Czech Republic. Race, Ethnicity and Education, 1-14. Advanced online publication. doi:10.1080/ 13613324.2016.1191698

Chancer, L. S., \& Watkins, B. (2006). Gender, race and class: An overview. Oxford: Blackwell Publishing. doi:10.4135/9781452243207.n5

Constantine, G. R. (2017). The Biological Basis of Performativity of Identity-Linking Scientific Evidence to Social Theory. Journal of Ethnic and Cultural Studies, 4(2), 88-95.

De Beco, G. (2017). Protecting the invisible: An intersectional approach to international human rights law. Human Rights Law Review, 17(4), 633-663. doi:10.1093/hrlr/ngx029

De Genova, N., (2015) Extremities and regularities: Regulatory regimes and the spectacle of immigration enforcement. In Y. Jansen, R. Celikates, \& J. De Blois (Eds.). The Irregularization of Migration: Detention, Deportation, Drowning. (pp.3-14). London: Rowman \& Littlefield International. doi:10.4337/9781785368066.00016

Edwards, A. (2017). Violence against women as sex discrimination: Judging the jurisprudence of the United Nations human rights treaty bodies. Equality and Non-Discrimination Under International Law, 389-448. doi:10.4324/9781315094410-17

Gagnon, A. G., \& Sauca, J. M., (Eds.). (2014), Negotiating diversity, identity, pluralism and democracy. Bruxelles, Bern, Berlin, Frankfurt am Main, New York, Oxford, Wien: Peter Lang International Academic Publishers. doi:10.3726/978-3-0352-6442-5

Helakorpi, J., Lappalainen, S., \& Mietola, R. (2018). Equality in the making? Roma and traveller minority policies and basic education in three Nordic countries. Scandinavian Journal of Educational Research, 1-18. doi:10.1080/00313831.2018.1485735

Hrabaňová, J. G., \& Albert, G. (2018). Untapped potential of Romani women's activism in contemporary Europe: Czech Republic. The Romani Women's Movement, 159-177. doi:10.4324/9781351050395-8

International Organization for Migration (IOM). (2003). Final Report on the Analysis of Contemporary Migration and the Establishment of Members of Roma Communities from the Slovak Republic in the Czech Republic (OAMP-948/2003).

Isin, E., (2015). Claiming European citizenship. In E. Isin \& M. Saward (Eds.), Enacting European Citizenship (pp.19-46). Cambridge: Cambridge University Press. doi:10.1017/cbo9781139524025.003

Issa, R., \& Mueller, J. C. (2017). Prejudice. In B. S. Turner (Ed.), The Wiley-Blackwell Encyclopedia of Social Theory.. doi:10.1002/9781118430873.est0287

Iwuanyanwu, P. N. (2019). What we Teach in Science, and What Learners Learn: A Gap that Needs Bridging. Pedagogical Research, 4(2), em0032. https://doi.org/10.29333/pr/5780

James, W. Y. (2019). Imprint of Racism: White Adult Males' Transformational Experience from Racial Antipathy to Racial Reconciliation. American Journal of Qualitative Research, 3(1), 93-116. https://doi.org/10.29333/ajqr/5813

Johnson, C., \& Hinton, H. (2019). Toward a Brillant Diversity. Journal of Culture and Values in Education, 2(1), $56-70$ Retrieved from http://cultureandvalues.org/index.php/JCV/article/view/27

Jovanovic, D. (2016). Roma Rights Journal of the European Roma Rights Centre. Human Rights Documents Online. doi:10.1163/2210-7975_hrd-9883-2015002

Kóczé, A., Zentai, V., Jovanovič, J., \& Vincze, E. (Eds.). (2019). The Romani women's movement. London: Routledge, doi:10.4324/9781351050395

Köllö, J. (2014). Patterns of integration: Low educated people and their jobs in Norway, Italy and Hungary. Retrieved from https://ideas.repec.org/p/has/bworkp/1315.html

Lafer, S., \& Tarman, B. (2019). Editorial 2019: (2)1, Special Issue. Journal of Culture and Values in Education, 2(1), i-v. Retrieved from http://cultureandvalues.org/index.php/JCV/article/view/34

Linehan, M. M. (2015). DBT Skills Training Handouts and Worksheets (2nd Ed.). New York: The Guilford Press. (p. 422) doi:10.1097/NMD.0000000000000387

Love, P. B., \& Kundu, R. (2016). Clinical Cases in Skin of Color (Online). Springer, doi:10.1007/9783-319-22392-6

Martincová, J., \& Andrysová, P. (2017). Professional preparation of students of social pedagogy in the czech republic. Journal of Social Studies Education Research, 8(1), 47-68.

Matras, Y. (2004). The role of language in mystifying and de - mystifying Gypsy identity. In N. Saul \& S. Tebbut (Eds.). The role of the Romanies (pp. 53-78). Liverpool: Liverpool University Press. doi:10.5949/liverpool/9780853236795.003.0005

Matras, Y. (2015). Customs and Traditions. The Romani Gypsies (pp. 83-124). doi:10.4159/harvard.9780674735958

Messing, V. (2014). Apart or together: motivations behind ethnic segregation in education across Europe. In C. Schiff \& J. Szalai (Eds.), Being “visibly different.” Post colonial, migrant and Roma youth 
in education across Europe (pp. 17-33). London: Palgrave Publication. doi:10.1057/9781137308634_2

Messing, V. (2017). Differentiation in the making: Consequences of school segregation of Roma in the Czech Republic, Hungary, and Slovakia. European Education, 49, 89-103, doi:10.1080/10564934.2017.1280336

Ministry of the Interior of the Czech Republic, report: five-more-years-of-injustice-segregated-educationfor-roma-in-the-czech-republic. (2008). Human Rights Documents Online. doi:10.1163/22107975 hrd-9883-0033

MŠMT and Institute for Information on Education. (2010). Human Rights Documents Online. doi:10.1163/2210-7975_hrd-9211-0377

Nelson, D. T. (2015). Handbook of prejudice, stereotyping, and discrimination (2nd ed.). New York: Psychology Press. doi:10.4324/9780203361993

New, W., \& Kyuchukov, H. (2018). Language education for Romani Children: Human rights and capabilities approaches. European Education, 50, 371-384. doi:10.1080/10564934.2017.1401437

Nguyen, V. T. (2018). Women and water management: A case study from the rural communities in Vietnam. American Journal of Qualitative Research, 2(1), 118-161.

Robnett, R. D., \& Anderson, K. J. (2017). Feminist identity among women and men from four ethnic groups. Cultural Diversity and Ethnic Minority Psychology, 23(1), 134-142. doi:10.1037/cdp0000095

Rostas, I., \& Kostka, J. (2014). Structural dimensions of Roma school desegregation policies in Central and Eastern Europe. European Educational Research Journal, 13(3), 268-281. doi:10.2304/eerj.2014.13.3.268

Ruggiu, I., (2016). Is begging a Roma cultural practice? Answers from the Italian legal system and anthropology. Liverpool University Press Online. doi:10.3828/rs.2016.2

Sardelič, J. (2017). The position and agency of the 'irregularized': Romani migrants as European semicitizens, Political Studies, 37(3), 332 -346. doi:10.1177/0263395716668537

Schlager, E. (2017). Policy and practice: A case study of U.S. foreign policy regarding the situation of Roma in Europe. Realizing Roma rights. doi:10.9783/9780812293876-004

Šimon, S., Ales, V., \& Švec, V. (2017). Study of the success and dropout in the higher education policy in Europe and V4 countries. Hungarian Educational Research Journal, 1, 43-56. doi:10.14413/herj.2017.01.04.

Stewart, M. (2017). Nothing about us without us, or the dangers of a closed-society research paradigm, Romani Studies 5(27), 125-146. doi:10.3828/rs.2017.8

Strubing, J., (2018). Forschungsethik und qualitative Forschung. Qualitative Sozialforschung: Eine komprimierte Einführung, 8, 218-229. doi:10.1515/9783110529920-008

Szalai, J., \& Schiff, C. (Eds.). (2014). Migrant, Roma and Post-Colonial youth in education across Europe. Being “visibly” different. London: Palgrave-McMillan. doi:10.1057/9781137308634

Weinerová, R. (2014). Anti-gypsyism in the Czech Republic: Czechs' perception of Roma in cultural stereotypes, Acta Ethnographica Hungarica, 59(1), 211-221, doi:10.1556/AEthn.59.2014.1.10

Figures: Theoretical studies focused on discrimination against Roma women in the Czech Republic 


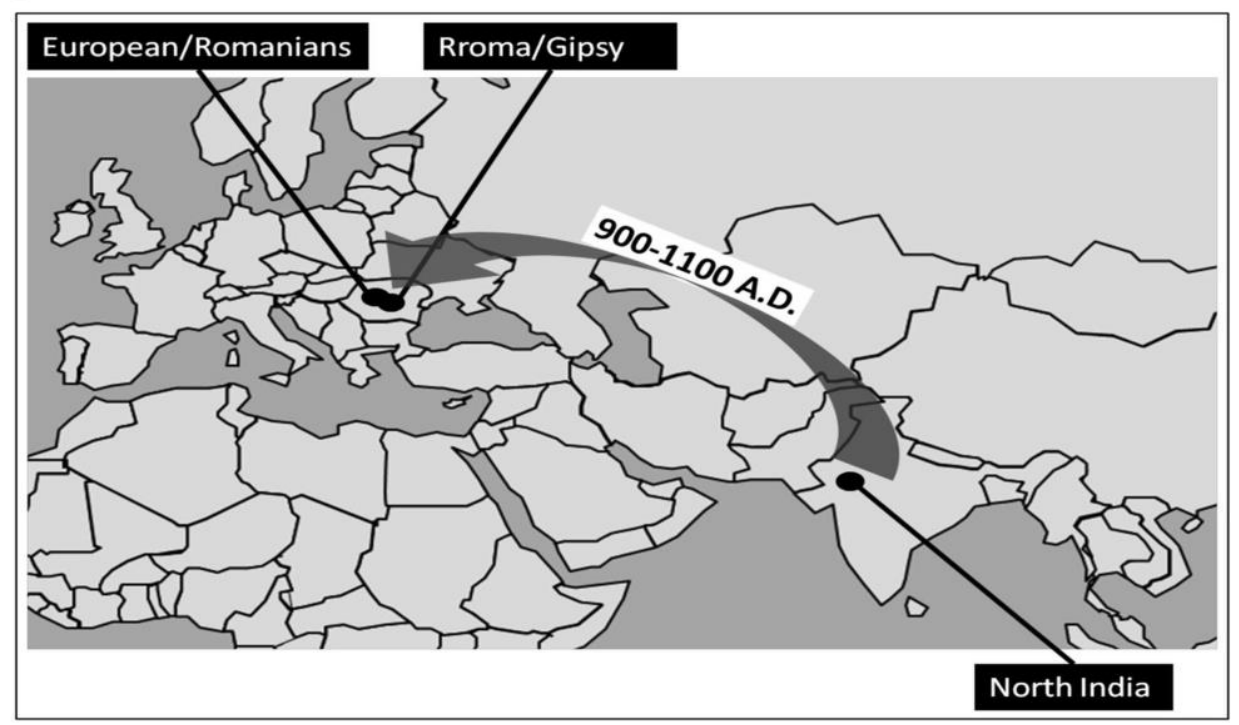

Figure 1. Migration of Roma people from northwest India to Europe Source: Copyright 2017, PNAS, LIVESCIENCE

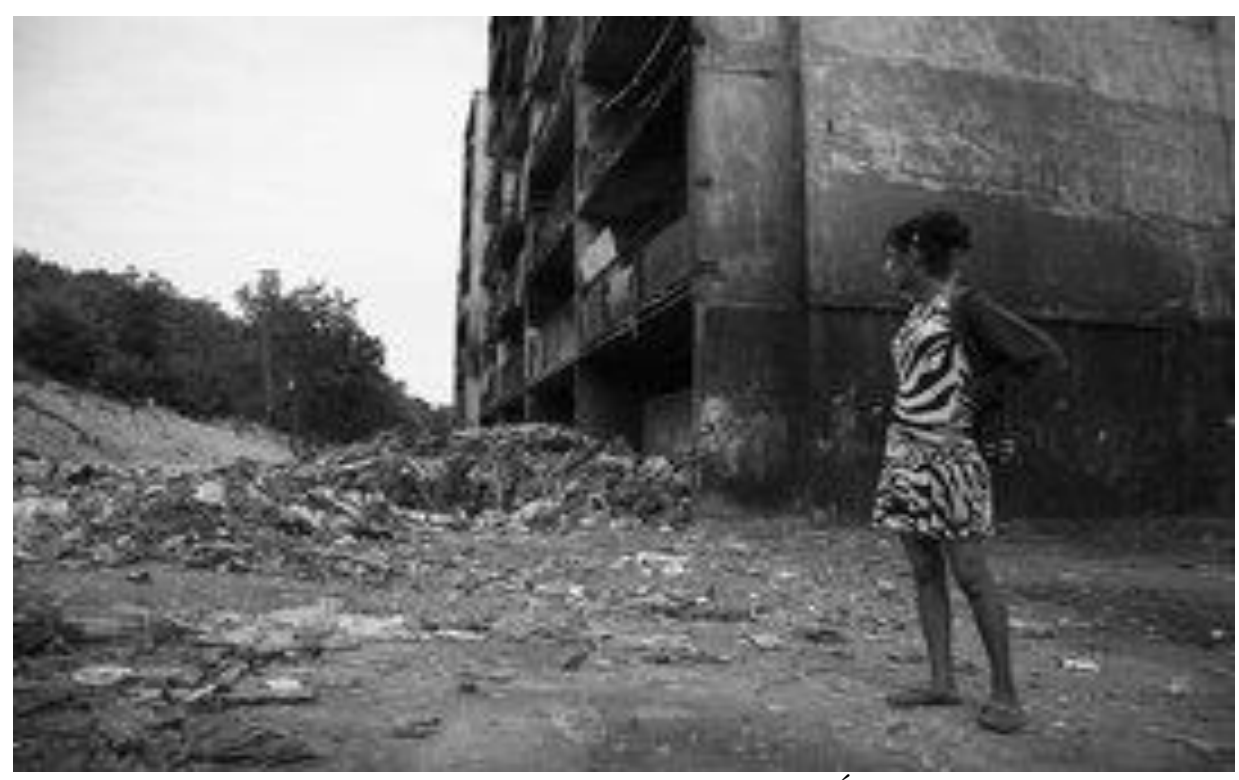

Figure 2. Roma Gheto in Region Ústí

Source: Copyright 2017, Reflex Newspaper 


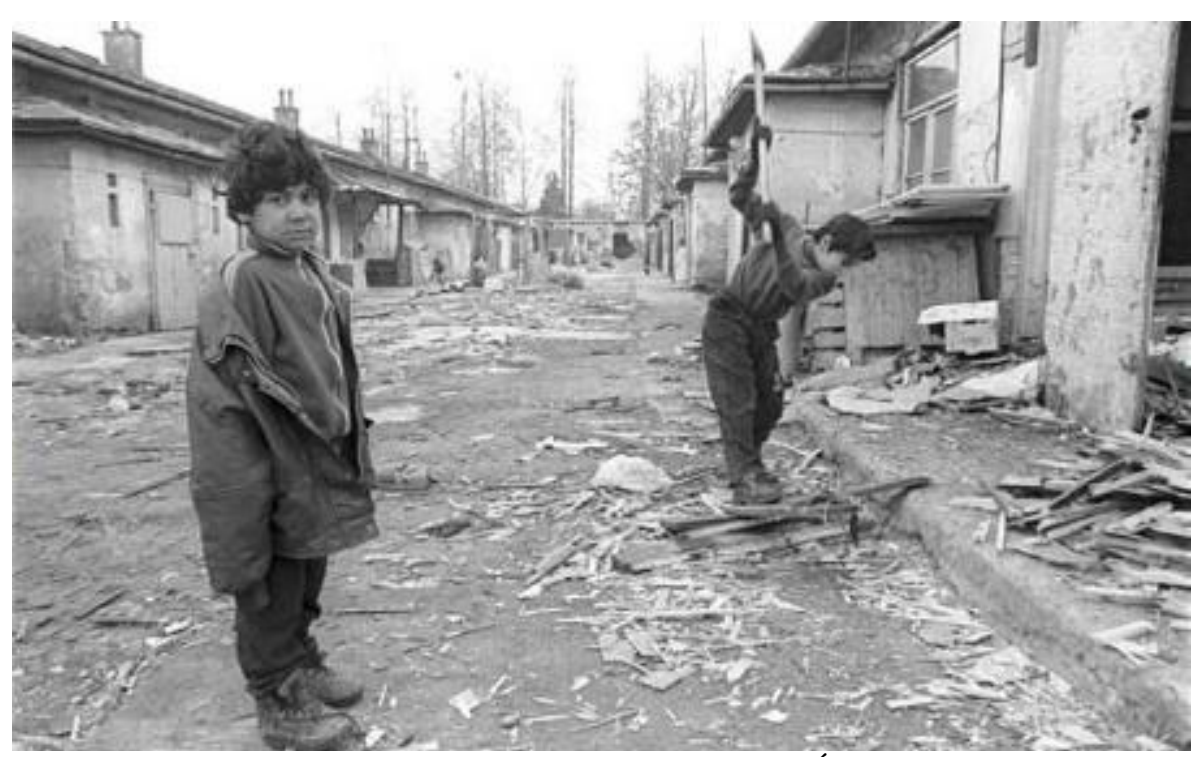

Figure 3. Roma Gheto in Region Ústí

Source: Copyright 2017, Zpravy.idnes.cz

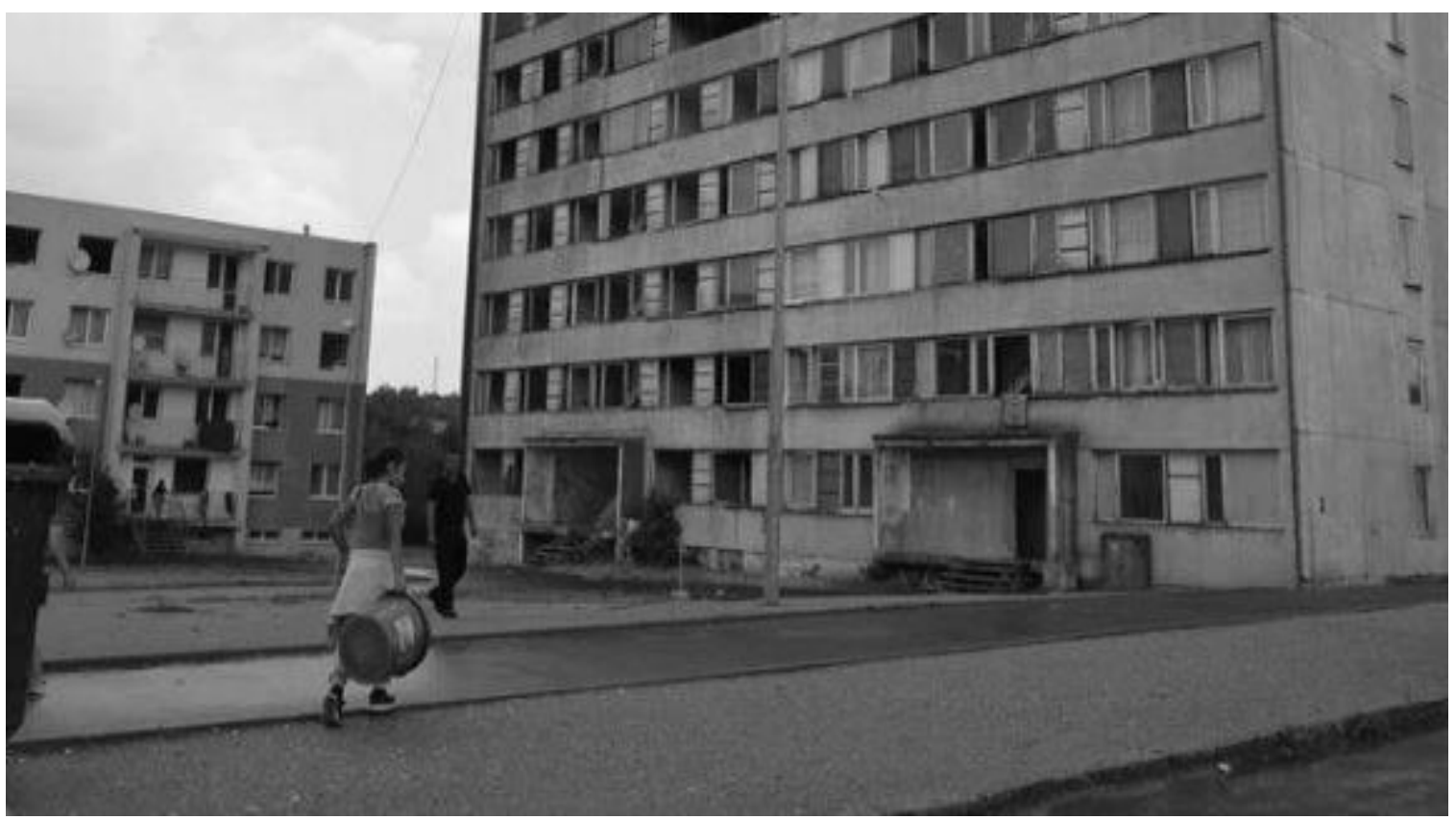

Figure 4. Roma Gheto in Region Litvinov

Source: Copyright 2017, Parlamentnilisty.cz 


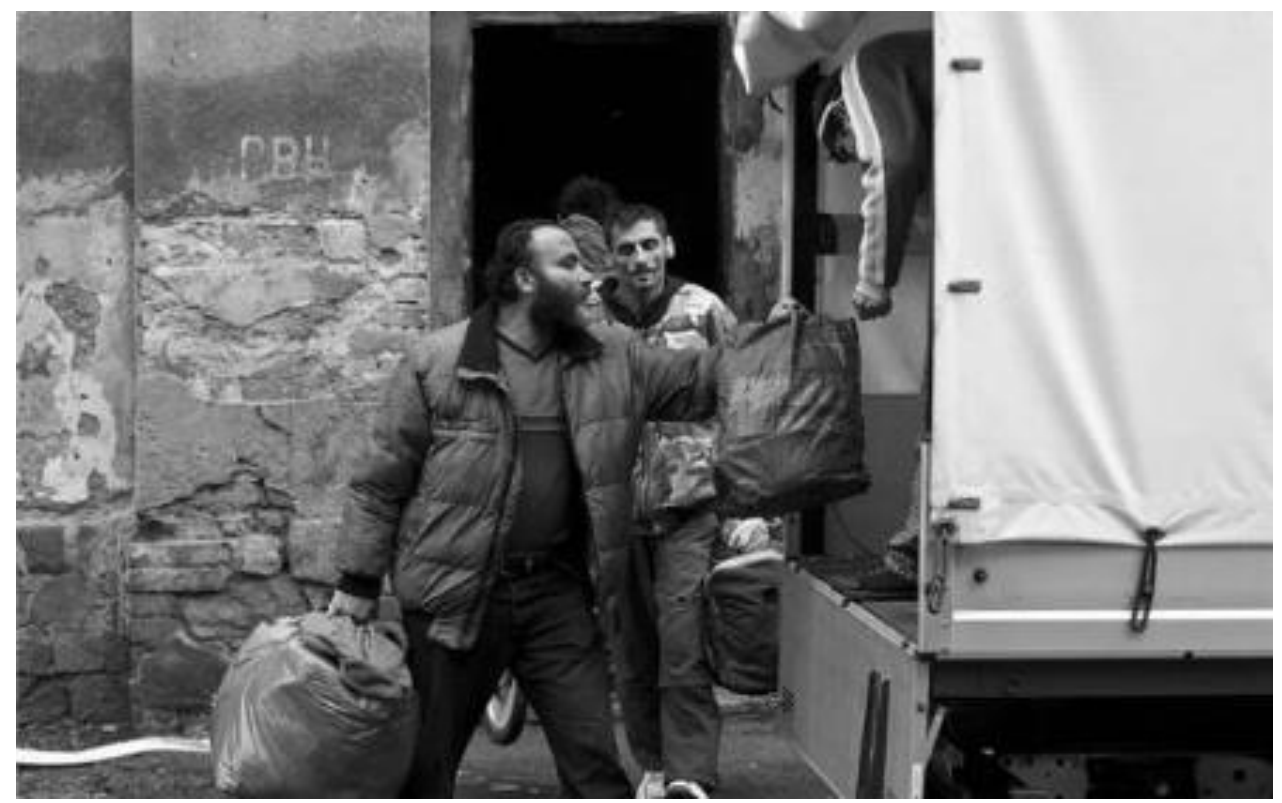

Figure 5. Migration of Roma populations' (From Slovak to Czech Republic) Source: Copyright 2017, Newspaper - Krajskelisty.cz

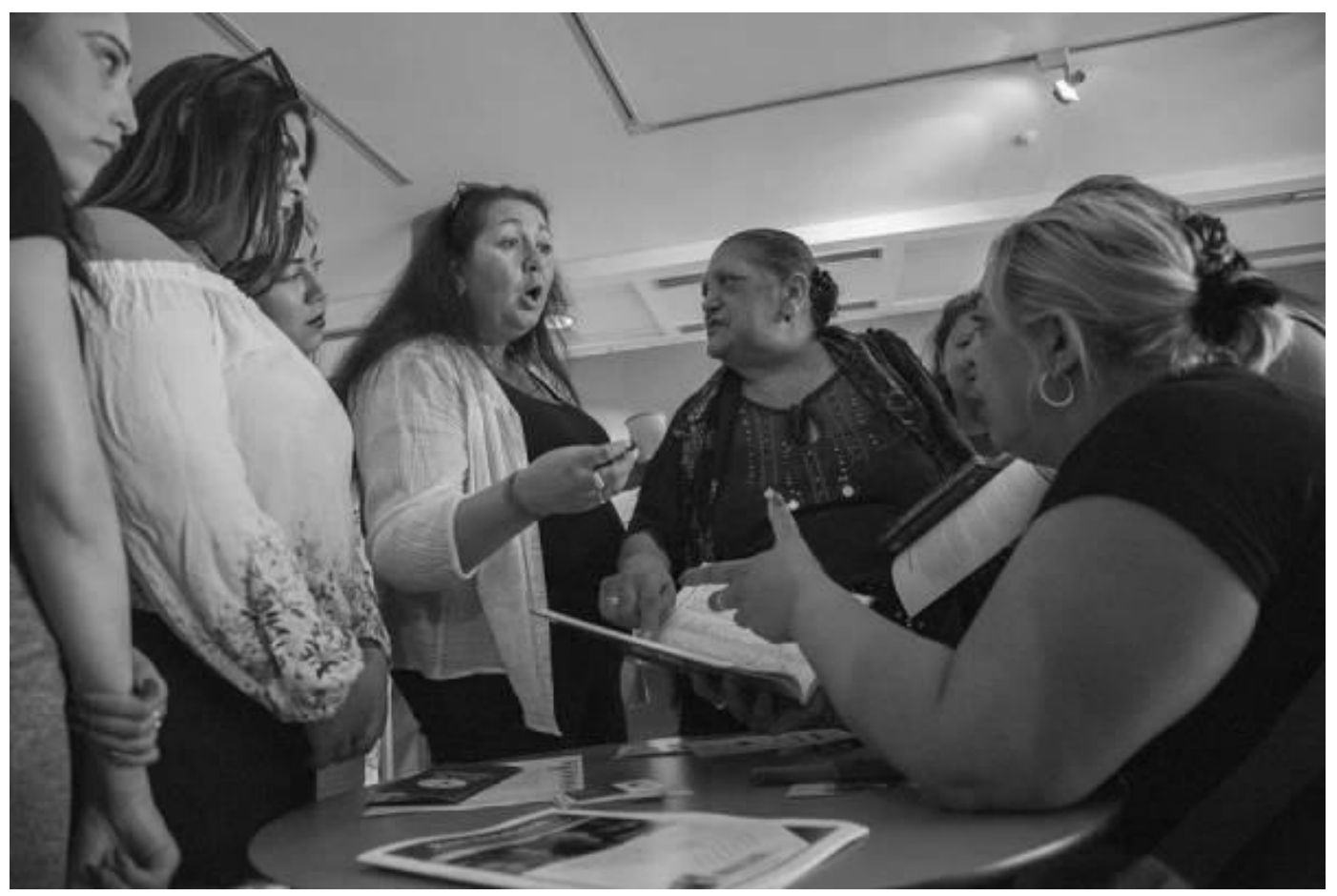

Figure 6. Discussion of Roma women's (Roma Ethnic Meeting on Women Discrimination) Source: Copyright 2018, Hatefree 


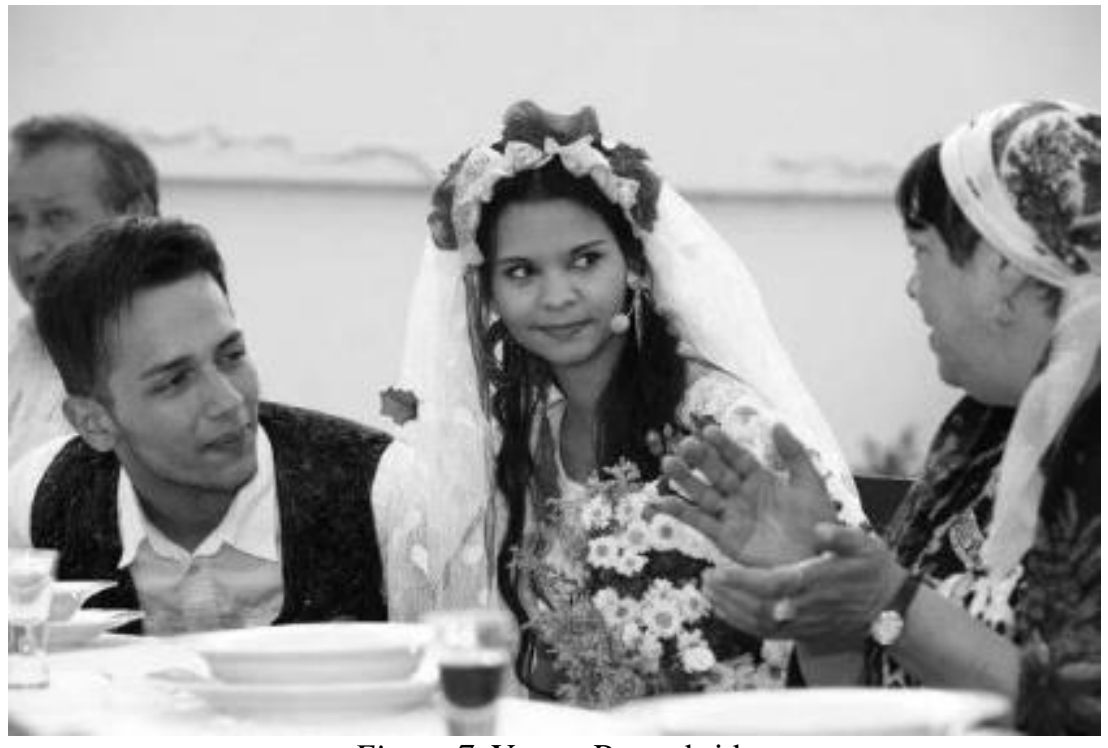

Figure 7. Young Roma bride

Source: Copyright 2018, Topzine.cz

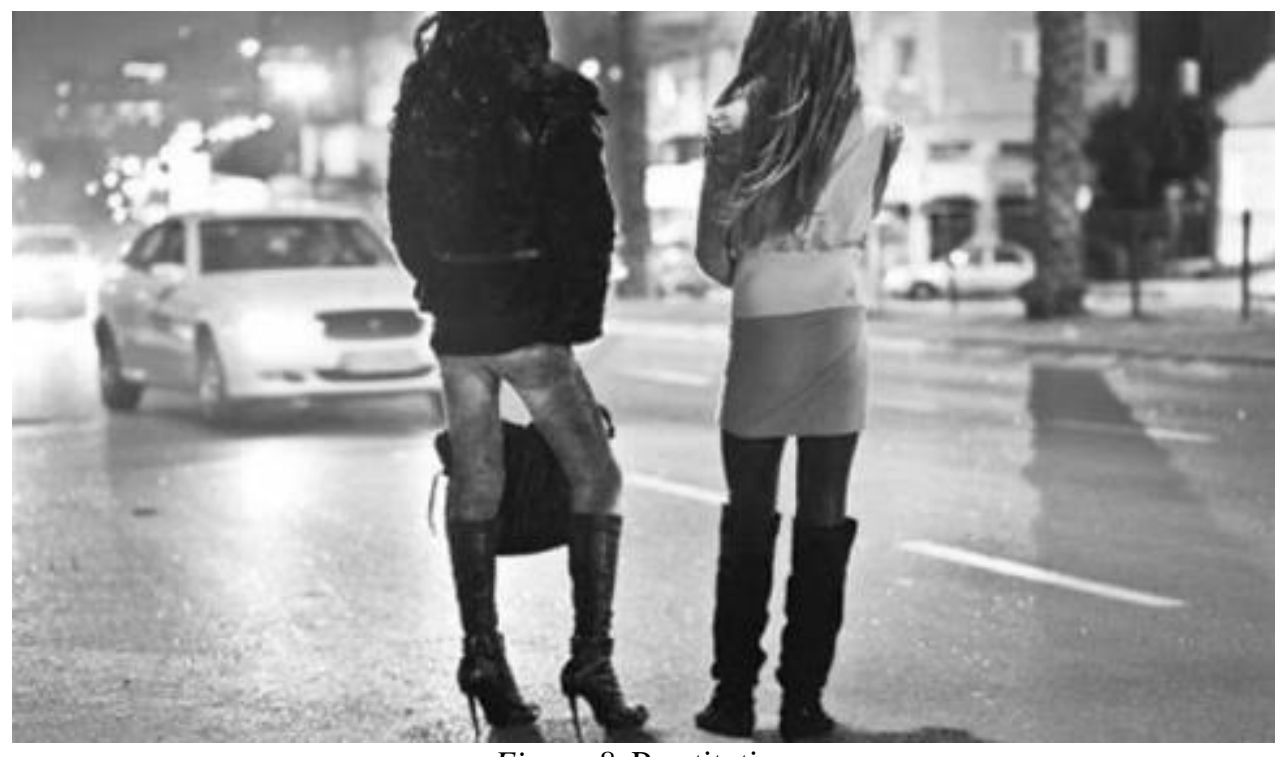

Figure 8. Prostitution

Source: Copyright 2018, Expres.cz 


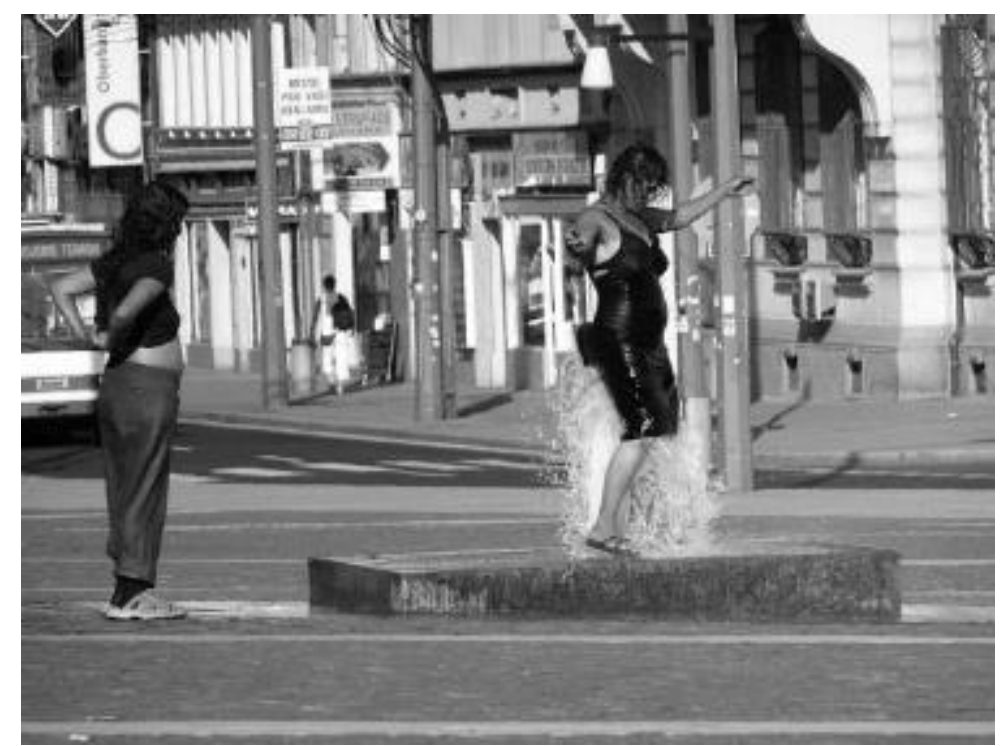

Figure 9. Roma woman in Region Ústí during the summer time Source: Copyright 2018, Krajskélisty.cz

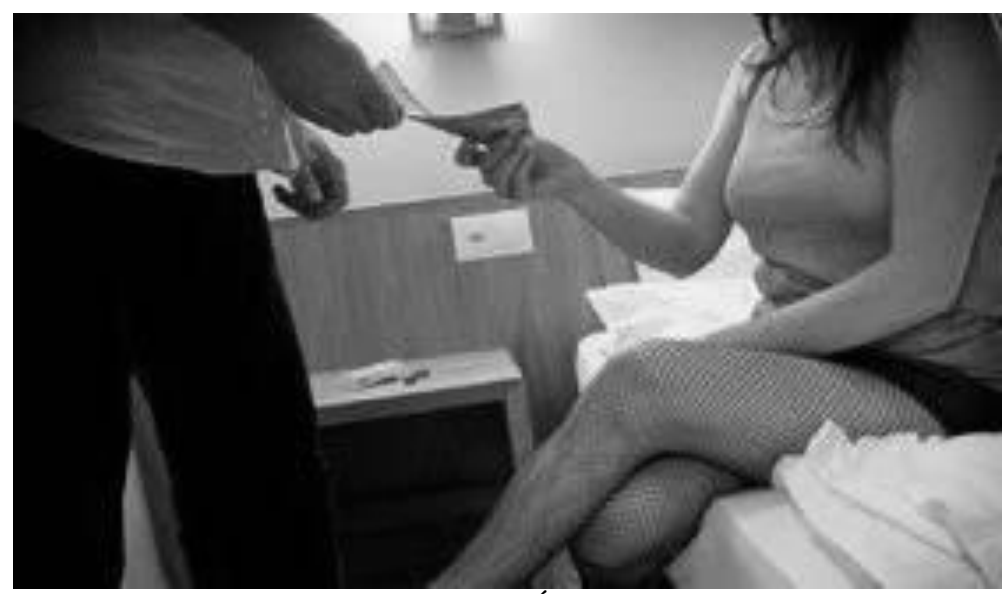

Figure 10. Roma woman in Region Ústí - ,closing the deal“ Source: Copyright 2017, Newspaper Blesk 